\title{
First record of the whitetip reef shark, Triaenodon obesus from the coast of Jalisco, western Mexico mainland
}

\author{
Antonio Corgos $^{*}$ and Alejandro Rosende-Pereiro
}

\begin{abstract}
Background: The whitetip reef shark, Triaenodon obesus, is distributed across the entire Indo-Pacific region, from South Africa and the Red Sea to Australia, Micronesia, the Pitcairn Islands, and Hawaii. It has also been reported in the Revillagigedo Archipelago and the Baja California peninsula, which are situated between 700 and $900 \mathrm{~km}$ to the west of Jalisco, and are the closest locations to the present study.

Results: On February 18, 2015 during an exploratory dive in the Tenacatita Bay a specimen of Triaenodon obesus was observed resting in a cave near a patch of coral reef at $4.5 \mathrm{~m}$ depth. Some photographs and videos were taken and species identification was confirmed.

Conclusions: The specimen found was clearly identified as T. obesus. The most probable dispersion way is from the Revillagigedo Archipelago to Baja California, followed by a southward movement through coastal areas from Sinaloa to Jalisco. A recent report of the presence of T. obesus in southern Nayarit state supports this hypothesis
\end{abstract}

Keywords: Shark, Range extension, Central Mexican Pacific, Mainland, Coastal

\section{Background}

The whitetip reef shark, Triaenodon obesus (Rüppell, 1837), is distributed across the entire Indo-Pacific region, from South Africa and the Red Sea to Australia, Micronesia, the Pitcairn Islands, and Hawaii. On the Eastern Pacific it is principally distributed between El Salvador and Ecuador, including the Galapagos Islands and the Isle of Coco (Randall, 1977; Compagno et al., 1995), although it has also been reported in the Revillagigedo Archipelago (Ochoa-Lopez et al. 1997; Love et al., 2005; Whitney et al., 2012a) and the Baja California peninsula (Whitney et al., 2012a), which are situated between 700 and $900 \mathrm{~km}$ to the west of Jalisco, and are the closest locations to the present study. T. obesus is associated with tropical coral reefs. This shark hunts nocturnally near reefs and caves (Randall, 1977; Compagno et al., 1995), and can be active during $42-67 \%$ of the nighttime (Whitney and Motta 2007; Zanella et al., 2012). The same caves that are used for hunting are utilized as shelter during the day

\footnotetext{
* Correspondence: acorgos@costera.melaque.udg.mx

Departamento de Estudios para el Desarrollo Sustentable de Zonas Costeras

-Universidad de Guadalajara, V. Gómez-Farías \#82, San Patricio-Melaque, 48980 Jalisco, Mexico
}

(Randall, 1977; Compagno et al., 1995; Whitney et al., 2012b), and can be occupied by several specimens simultaneously, with a tendency to use the same cave over long periods of time (Nelson \& Johnson, 1980; Whitney et al., 2012a).

The whitetip reef shark diet is composed of diverse species of reef fish such as snapper, surgeonfish or goatfish; it also consumes lobster, octopus, and crab (Randall, 1977; Compagno et al., 1995). Although it can be found at depths ranging from 1 to $330 \mathrm{~m}$, it usually inhabits between 10 and $40 \mathrm{~m}$ (Randall, 1977). This is a viviparous shark, with slow growth and a maximum registered total length (TL) of $2.13 \mathrm{~m}$ (Compagno et al., 1995). Females give birth to between 1 and 5 offspring (average 2), with sizes near $60 \mathrm{~cm}$ TL (Randall, 1977; Compagno et al., 1995; Robbins, 2006). Sexual maturation is reached at a size of between $112-116 \mathrm{~cm}$ TL and approximately 7 years of age in males, and $114-122 \mathrm{~cm}$ TL and approximately 8 years in females (Robbins, 2006).

\section{Methods}

During the research period a local fisherman alerted us to the presence of several specimens of a shark with 
white tips on their fins in the zones of "Tenacatita" $\left(19^{\circ}\right.$ $\left.16^{\prime} 49.8^{\prime \prime} \mathrm{N}, 104^{\circ} 52^{\prime} 14.1^{\prime \prime} \mathrm{W}\right)$ and "Los Frailes" (19 $19^{\circ}$ ' $\left.22.1^{\prime \prime} \mathrm{N}, 104^{\circ} 57^{\prime} 39.9^{\prime \prime} \mathrm{W}\right)$, observed while night-diving for lobster. On February 18, 2015 during an exploratory dive in the Tenacatita Bay a specimen of Triaenodon obesus was observed resting in a cave near a patch of coral reef at $4.5 \mathrm{~m}$ depth (Fig. 1). Species identification was achieved through observation of distinctive features both in the field and photographs, as described in Compagno et al. (1995). Photographs of the first dorsal fin were also used to identify the specimen throuth the new software iSharkFin (FAO 2014).

\section{Results}

The specimen presented the distinctive features described in Compagno et al. (1995): a) moderately large dorsal fin that originates well behind the free rear tips of the pectoral fins; b) white tips on the first dorsal and upper caudal fin lobes. A positive identification was also obtained from a photograph of the first dorsal fin using the new software iSharkFin (FAO 2014). There are only three known species of sharks that have white-tipped fins: Carcharhinus longimanus, C. albimarginatus and Triaenodon obesus. The first is completely oceanic, larger in size, and has a wide white-tipped dorsal fin; $C$. albimarginatus has a dorsal fin that originates at the tip of the pectoral fins, which have white posterior margins. Therefore, there is no doubt that the specimen observed is $T$. obesus. Taking into account its size $(\approx 1.8 \mathrm{~m} \mathrm{TL})$, we believe this is an adult at least 8 years of age.

\section{Discussion}

The presence of a specimen of T. obesus on the southern coast of Jalisco has three possible explanations. The first suggests that the shark travelled directly through the open ocean from the Revillagigedo Archipelago to Jalisco (about 720-900 km). The second posits that the shark moved from the Revillagigedo Archipelago to the

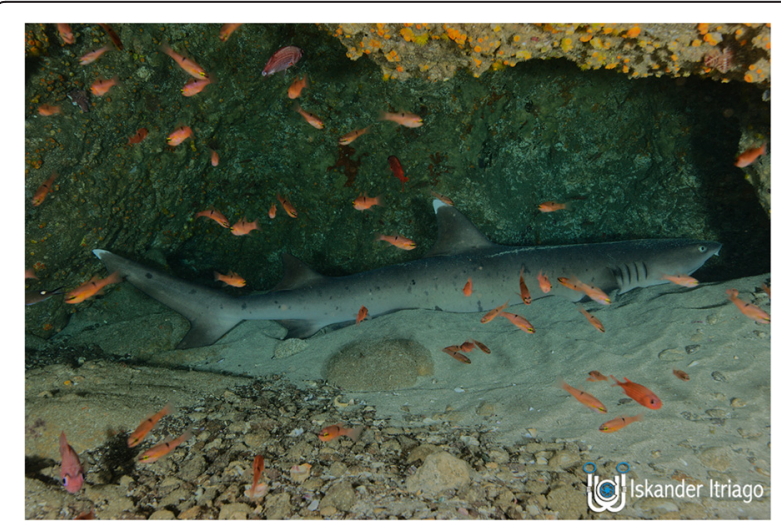

Fig. 1 Specimen of Triaenodon obesus observed on the coast of Jalisco, Mexico southern Baja California peninsula (about $460 \mathrm{~km}$ ), crossed the Gulf of California towards the coast of Sinaloa (about $320 \mathrm{~km}$ ) and then dispersed southwards along the coast to Jalisco (about $630 \mathrm{~km}$ from Sinaloa). The last explanation suggests that the shark travelled northwards nearly $2000 \mathrm{~km}$ along the coast from El Salvador. This species is sedentary and spends the majority of the time resting in caves (Randall, 1977; Nelson \& Johnson, 1980, Whitney and Motta 2007), but also travels several tens of kilometers in search of adequate habitat (Whitney et al., 2012b), a behavior commonly seen in other reef sharks such as Carcharhinus perezi (Chapman et al., 2005) or C. amblyrhynchos (Heupel et al., 2010). Randall (1977) suggested the existence of large scale movements of $T$. obesus that would explain its wide distribution in the Indo-Pacific region. Whitney et al. (2012a) proposed that due to occasional events (such as a large storm) some specimens become disoriented and lost in the middle of the ocean, but thanks to their resting phase (with reduced metabolism) they could survive long periods in oligotrophic ocean waters. This could also explain their expansion across tropical zones, and would be the most likely cause for the displacement of this species from the Revillagigedo Archipelago to the coast of Jalisco or Baja California, as between the months of June and November there are numerous storms and hurricanes that affect a wide area including the Revillagigedo Archipelago and the entire coast of the central Mexican Pacific. The possibility that this organism arrived from the coast of El Salvador is unlikely, considering the distance and particularly the amount of fishing gear it would have encountered along the way. The presence of $T$. obesus in Baja California (probably southern Baja) several years before than in Jalisco (Whitney et al., 2012a) suggests a species dispersion from the Revillagigedo Archipelago to Baja California, followed by a southward movement through coastal areas from Sinaloa to Jalisco. A recent report of the presence of $T$. obesus in Marietas islands and Bahía de Banderas (southern Nayarit state, José Adolfo Tortolero, pers. comm.) supports this hypothesis. However, more reports (including the date sighted) from Sinaloa to Jalisco would be useful in determining actual dispersion patterns. This case highlights the importance of reporting the range extension of shark species.

\section{Conclusions}

The specimen found was clearly identified as T. obesus.

Due to distance to nearest locations reported, a dispersion way directly from the Revillagigedo Archipelago $(720-900 \mathrm{~km})$ or along the coast from El Salvador $(2000 \mathrm{~km})$ is unlikely.

The most probable dispersion way is from the Revillagigedo Archipelago to Baja California $(460 \mathrm{~km})$, followed 
by a southward movement through coastal areas from Sinaloa to Jalisco $(630 \mathrm{~km})$. A recent report of the presence of $T$. obesus in southern Nayarit state supports this hypothesis.

\section{Acknowledgments}

We want to thank Juan Carlos Quiroz "Chimuikis" and José Adolfo Tortolero for the information regarding his sightings of T. obesus while diving, and Iskander Itriago for providing the photograph included in the present work.

\section{Funding}

This research was supported by the University of Guadalajara through P3e research funds of the Departamento de Estudios para el Desarrollo

Sustentable de Zonas Costeras.

\section{Authors' contributions}

AC participated in the field sampling, protograph editing, writing, translation and editing the text of the manuscript and review and rewriting the manuscript drafts following editors' revisions. AR-P participated in the field sampling and writing the first version of the manuscript. Both authors read and approved the final manuscript.

\section{Competing interests}

The authors declare that they have no competing interests.

Received: 16 June 2016 Accepted: 17 June 2016

Published online: 27 June 2016

\section{References}

Chapman DD, Pikitch EK, Babcok E, Shivji MS. Marine reserve design and evaluation using automated acoustic telemetry: a case-study involving coral reef-associated sharks in the Mesoamerican Caribbean. Mar Technol Soc J. 2005;39:42-53.

Compagno L, Krupp F, Schneider W. Tiburones. In Fischer W, Krupp F, Schneider W, Sommer C, Carpenter K, Niem V, (eds). Guía FAO para la identificación de especies para los fines de la pesca. Pacífico centro-oriental, Volumen II. Vertebrados Parte I. Roma-Italia, FAO;1995. pp. 647-743.

FAO (2014-2015) International plan of action for the conservation and management of sharks - Web site. iSharkFin. FI Institutional Websites. In: FAO Fisheries and Aquaculture Department [online]. Rome. Updated 24 March. [cited 23 Jun 2016]. http://www.fao.org/ipoa-sharks/tools/software/isharkfin/en.

Heupel MR, Simpfendorfer CA, Fitzpatrick R. Large-scale movements and reef fidelity of Grey Reef Sharks. PLoS ONE. 2010;5(3):e9650. doi:10.1371/journal. pone.0009650.

Love MS, Mecklenburg CW, Mecklenburg TA, Thorsteinson LK. Resource Inventory of Marine and Estuarine Fishes of the West Coast and Alaska: A checklist of North Pacific and Arctic Ocean species from Baja California to the AlaskaYukon border, US Geological Survey, Biological Resources Division. OCS Study MMS 2005-030 and USGS/NBII 2005-001. 2005. p. 288.

Nelson DR, Johnson RH. Behavior of the reef sharks of Rangiroa, French Polynesia. National Geographic Society Research Reports. 1980;12:479-99.

Ochoa-Lopez E, Villavicencio-Garayzar C, Ruiz-Gaytan A. First record of the whitetip reef shark, Triaenodon obesus in the west coast of Mexico Revillagigedo Archipelago. Revista de Biología Tropical. 1997:44(3)/45(1), 687-688.

Randall JE. Contribution to the biology of the whitetip reef shark (Triaenodon obesus). Pac Sci. 1977:31(2):143-64.

Robbins W. Abundance, demography and population structure of the grey reef shark (Carcharhinus amblyrhynchos) and the whitetip reef shark (Triaenodon obesus) (Fam. Carcharhinidae). PhD thesis. James Cook Universit., Townsville, Australia; 2006.

Rüppell WPES. Neue Wirbel. Faun. Abyssinien. Fische Rothen Meeres. 1837;(11):64 pl. 18, fig. 2.

Whitney N, Motta P. Cleaner host posing behavior of whitetip reef sharks (Triaenodon obesus) in a swarm of hyperiid amphipods. Coral Reefs. 2007;27(2):363.

Whitney NM, Robbins WD, Schultz JK, Bowen BW, Holland KN. Oceanic dispersal in a sedentary reef shark (Triaenodon obesus): genetic evidence for extensive connectivity without a pelagic larval stage. J Biogeography. 2012a;39:1144-1156.
Whitney NM, Pyle RL, Holland KN, Barcz JT. Movements, philopatry, and reproductive seasonality in the whitetip reef shark (Triaenodon obesus) from community based photo-identification. Environ Biol Fishes. 2012b;93:121136.

Zanella I, López-Garro A, Golfín-Duarte G, Saenz JC. Abundancia, tamaño y estructura poblacional del tiburón punta blanca de arrecife, Triaenodon obesus (Carcharhiniformes: Carcharhinidae), en Bahía Chatham, Parque Nacional Isla del Coco, Costa Rica. Rev Biol Trop. 2012;60(3):339-46.
Submit your next manuscript to BioMed Central and we will help you at every step:

- We accept pre-submission inquiries

- Our selector tool helps you to find the most relevant journal

- We provide round the clock customer support

- Convenient online submission

- Thorough peer review

- Inclusion in PubMed and all major indexing services

- Maximum visibility for your research

Submit your manuscript at www.biomedcentral.com/submit 